\title{
The Review Book review
}

\section{ADDRESS FOR CORRESPONDENCE}

\section{Martin Wilkinson}

NHS West Midlands, 213 Hagley Road,

Birmingham, B16 9RG, UK.

\section{E-mail: martin.wilkinsondwestmidlands.nhs.uk}

\section{Edward Ng,}

GP, Ley Hill Surgery, Birmingham.

\section{KK Cheng,}

Professor of Public Health and Primary Care University of Birmingham, Birmingham; Honorary Head of Department of General Practice, Peking University Health Science Centre, Beijing.

\section{DOI: 10.3399/bjgp12X656946}

\section{REFERENCES}

1. Browne $\mathrm{D}$. The long march to primary health care in China: from a collectivism to market economics. Public Health 2001; 115(1): 2-3.

2. Eggleston $\mathrm{K}$, Li L, Meng $Q$, Lindelow $M$, Wagstaff $M$. Health service delivery in China: a literature review. Health Econ 2008; 17(2): 149-165.

3. Chinese Academy of Social Sciences. The analysis and prediction of the social position in China: 2011 [in Chinese]. Beijing: Chinese Academy of Social Science Press, 2011.

4. Yip W, Hsiao W, Chen W, et al. Early appraisa of China's huge and complex health-care reforms. Lancet 2012; 379(9818): 833-842.

5. People's Republic of China Ministry of Health Statistical bulletin on the development of health services in China: 2011 [in Chinese]. 2012. http://www.moh.gov.cn/publicfiles/ business/htmlfiles/mohwsbwstjxxzx/ s7967/201204/54532.htm laccessed 20 Aug 2012).

6. Tang J, Liu B, Ma K. Traditional Chinese medicine. Lancet 2008; 372(9654): 1938-1940.

7. The Xinhua News. China uses education reform and health reform to relieve the storage of general practitioner [in Chinese]. Xinhua News 2012; 6 Dec: http://news.xinhuanet.com/politics/201112/06/c 111221925.htm laccessed 20 Aug 2012).

8. State Council, People's Republic of China Opinions of the establishment of the general practitioner system, government document [in Chinese]. 2011. http://www.gov.cn/zwgk/201107/07/content_1901099.htm laccessed 20 Aug 2012).

9. Yang $Y$, Yang D. Community health service centers in China, not always trusted by the populations they serve? China Economic Review 2009; 20: 620-624.

10. Bhattacharyya O, Yin D, Wong S, Chen B. Evolution of primary care in China 1997-2009. Health Policy 2011; 100(2-3): 174-180.

11. Chen Z. Launch of the health-care reform plan in China. Lancet 2009; 373(9672): 1322-1324.

\section{GLOBAL PERSPECTIVE ON WAR, GENDER AND HEALTH; THE SOCIOLOGY AND ANTHROPOLOGY OF SUFFERING HANNAH BRADBY AND GILLIAN LEWANDO HUNDT \\ Ashgate Publishing Ltd, 2010 \\ HB, 157pp, €55.00 9780754675235}

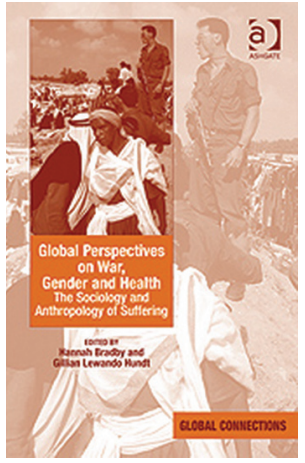

War and suffering go together akin to a horse and cart. As with love, aggression is an animal instinct and human nature. Wars are usually between two unequal parties and sometimes between equals, usually for monetary gains. World Wars I and II are the only vivid examples of confrontation between two equals. Rarely two lions may fight each other but often a lion attacks a lamb. I remember an Indian story; a thirsty lion drank water from a canal. He felt hungry. He saw a lamb drinking water a few yards down stream. The lion was very civilised. He went to the lamb and said, You have polluted my water and I will eat you'. The lamb said, 'Sir, I was on the lower level of the canal and I did not pollute your water'. The lion told the lamb, 'You are arguing with me, how dare you, so / shall eat you', and he meant it.

Suffering is an inevitable result of wars, that affect not only soldiers but also women, children, older, disabled, and weak people in the whole country. Suffering is a dehumanising experience with pain and sorrow. To suffer is to lose sight of one's personhood and a sense of connection with anything beyond oneself. Recovery is regaining one's sense of human, embodied self and its connection with the world. In addition, the prejudices based on sex, age, ethnic, and sexual identity can also cause suffering. This thought-provoking, wellwritten book focuses on war, sex, health,

\section{ADDRESS FOR CORRESPONDENCE}

Bashir Qureshi

32 Legrace Avenue, Hounslow, TW4 7RS, UK

E-mail: drbashirqureshiahotmail.com

suffering, and global connections.

The meaning of suffering and its place in human life have previously been important issues for religious and metaphysical thinkers. With the emergence of modernity and it's rational, scientific approach to problems, the role of God, gods, and fate in suffering has retreated. The pursuit of economic wealth through expanding commodity markets has been a central strategy for avoiding and dealing with the suffering of poverty and sickness. Modern science has improved health and prolonged life, where possible. In its eight chapters, 14 authors have skilfully described the sad reflection of the widespread nature of suffering with war and conflicts globally, especially in Uganda, Morocco, India, Pakistan, Bangladesh, and Northern Ireland. The authors accept that wars are inevitable but describe how there is a vision of peaceable life, survival, health, and happiness. Sociologists, anthropologists, politicians, public health professionals, GPs, and academics would find this book an interesting, readable, concise, and authentic research collection from across the globe.

\section{Bashir Qureshi,}

Formerly, Elected Member of the RCGP Council and Emeritus Vice President, Royal Society for Public Health, London.

DOI: 10.3399/bjgp12X656955 